\title{
Spatial distribution of the geochemical associations in the Babyak Mo-Ag-Au-W-Bi-base metal deposit, Western Rhodopes (Bulgaria): application of factor analysis
}

\section{Пространствено разпределение на геохимичните асоциации в Mo-Ag-Au-W-Bi-полиметално находище Бабяк, Западни Родопи (България): приложение на факторен анализ}

\author{
Milen Stavrev', Kamen Popov ${ }^{2}$, Kalin Ruskov², Silvia Chavdarova ${ }^{1}$, Atanas Hikov', Irena Peytcheva ${ }^{1}$ \\ Милен Ставрев ${ }^{1}$, Камен Попов ${ }^{2}$, Калин Русков ${ }^{2}$, Силвия Чавдарова ${ }^{1}$, Атанас Хиков ${ }^{1}$, Ирена Пейчева ${ }^{1}$ \\ ${ }^{1}$ Geological Institute, Bulgarian Academy of Sciences, Acad. G. Bonchev Str., bl. 24, 1113 Sofia; E-mail: mstavrev@geology.bas.bg \\ ${ }^{2}$ University of Mining and Geology St. Ivan Rilski, Prof. Boyan Kamenov Str., 1700 Sofia, Bulgaria
}

\begin{abstract}
A new approach combining geochemical and mineralogical studies with statistical methods in the Babyak Mo-Ag-Au-W-Bi-base metal deposit is presented. The data are used for 3D geological modelling of the deposit and help to better understand the zonation of the elements and the complex geological evolution of the deposit.
\end{abstract}

Keywords: Western Rhodopes, Babyak ore deposit, 3D modelling, RBF interpolation, factor analysis.

\section{Introduction}

The Bulgarian territory is well-known by the diversity of ore deposits and occurrences of different origin and age. Significant $\mathrm{Pb}-\mathrm{Zn}$ mineralization (e.g. Madan and Laki ore fields) and Au-Ag-base-metal deposits (e.g. Krumovgrad and Spahievo ore fields) are located in the Rhodope Mountains. Most authors refer the Rhodopes as a large tectono-metallogenic zone on the Balkan Peninsula that was formed during the Cenozoic period of the Africa-Europe convergence (e.g. Ivanov, 2017). The Late Alpine evolution in the western parts of the Rhodope zone is characterized by intensive granitoid magmatism and the main composite body in the area is the Rila-West Rhodopes granitoid batholith (RWRGB). It consists of Upper Cretaceous granodiorites and Upper Cretaceous-Paleogene granites showing different geochemical, isotopic, petrological, mineralogical and structural features (e.g. Kamenov et al., 1999; von Quadt, Peytcheva, 2005; Stavrev et al., 2020a; Peytcheva et al., 2021). The granitoid magmatism produced numerous hydrothermal zones of alteration and $\mathrm{Mo}, \mathrm{W}, \mathrm{U}, \mathrm{Au}, \mathrm{Ag} \pm \mathrm{Pb}, \mathrm{Zn}, \mathrm{Cu}$ ore mineralization (e.g. Georgiev et al., 2019; Popov, Popov, 2019). To better understand the spatial distribution of the ore bodies and the related geochemical associations we applied a new approach combining the geochemical and mineralogical studies (Stavrev et al., 2018, 2020b) with statistical methods in the Babyak Mo-Ag-Au-W-Bi-base metal deposit (Deltchev, Dimitrov, 1964). The results were then used for 3D geological modelling of the deposit that may contribute to further clarify the zonation and better understand the complex geological evolution of the deposit.

\section{Geological background}

The Babyak Mo-Ag-Au-W-Bi-base metal ore deposit (Deltchev, Dimitrov, 1964; Popov, Popov, 2019) is located about $30 \mathrm{~km} \mathrm{NE}$ from the town of Razlog and about $180 \mathrm{~km} \mathrm{SE}$ of Sofia. The main magmatic rocks in the area include coarse to medium-grained biotite granites with irregular to vein pegmatites ( \pm aplites). These rocks are intruded into biotite to two-mica orthogneisses, amphibolites and parametamorphic rocks (schists, marbles, calcschists) of the Jurassic Sarnitsa lithotectonic unit (Sarov et al., 2008).

Five main prospects are distinguished in Babyak deposit: Duyova Dupka, Kardashovi Kolibi, Copper Anomaly, Babyak-East and Mehovtsi. The ore mineralization at the deposit is hosted in the brittle contacts between different lithologies or fills faults and cracks in the rocks. About 17 bigger zones with their apophyses are distinguished. The zones are repre- 
sented mainly by quartz to quartz-pegmatite veins, which include sulfide and sulfosalt veinlets, nests and disseminations. Pyrite and molybdenite are the most common ore minerals, while galena, sphalerite, native gold, chalcopyrite, Bi-bearing phases, etc. are less distributed. The ore-forming process is accompanied by moderate to strong wall-rock hydrothermal alterations comprising mostly phyllic, silicification and greisenlike types. The altered zones mark one main ore-bearing system of NNE-SSW faults steeply dipping to the west and secondary NW-SE fault system with a steep dip to the NE or SW. Part of the ore-controlling faults might be related to the main extensional tectonic structure in the region - the Babyak-Grashevo shear zone (Sarov, 2012).

\section{Samples and methodology}

For the present study we used analytical data (fouracid digestion and determination of 41 elements using ICP-OES technique) of 6572 whole-rock samples collected from 156 drill holes and 165 trenches during the exploration activities in the Babyak area for the period 2011-2017 (kindly provided by Euromax Services Ltd., Bulgaria). For the distinction of the geochemical associations, we used statistical tools that were described and applied by Popov $(2002,2016)$. The procedures were performed in the following order: preliminary data preparation $\rightarrow$ univariate statistical analysis and correlation matrix of the elements $\rightarrow$ cluster analysis using hierarchical clustering method $\rightarrow$ factor analysis and 3D modelling of the geochemi- cal associations. The sequence of statistical procedures was performed using the free Jamovi software, version 1.8.4.0. Some of the elements $(\mathrm{B}, \mathrm{Hg}, \mathrm{Li}, \mathrm{S}$, $\mathrm{Sc}, \mathrm{Sn}, \mathrm{Te}, \mathrm{Y}, \mathrm{Zr}, \mathrm{Th}, \mathrm{U})$ were excluded in order to determine the most representative group of elements for the deposit. In the study was applied the principal component analysis (PCA) which is the most popular variety of factor analysis in combination with normalized "varimax" rotation. The geological modelling of the calculated factor weights was processed by Leapfrog Geo 3D software, version 5.0.4 using Radial Basis Function (RBF) for data interpolation.

\section{Spatial distribution characteristics and discussion of the results}

The present work is based on the spatial correlations of 30 elements (Ag, $\mathrm{Al}, \mathrm{As}, \mathrm{Au}, \mathrm{Ba}, \mathrm{Be}, \mathrm{Bi}, \mathrm{Ca}, \mathrm{Cd}$, $\mathrm{Co}, \mathrm{Cr}, \mathrm{Cu}, \mathrm{Fe}, \mathrm{Ga}, \mathrm{K}, \mathrm{La}, \mathrm{Mg}, \mathrm{Mn}, \mathrm{Mo}, \mathrm{Na}, \mathrm{Ni}, \mathrm{P}$, $\mathrm{Pb}, \mathrm{Sb}, \mathrm{Sr}, \mathrm{Ti}, \mathrm{Tl}, \mathrm{V}, \mathrm{W}, \mathrm{Zn}$ ). They are divided into 7 groups of factors, which are considered as the basic geochemical associations in the region of Babyak deposit. The association of ([Al, K, Ga, $\mathrm{Na}, \mathrm{Tl}] \mathrm{Ba}, \mathrm{Sr}$ ) $\pm \mathrm{Ti}$, V from factor 1 as well as this one of ([P, V, Ti, $\mathrm{Mg}] \mathrm{Fe}, \mathrm{Co}) \pm \mathrm{La}, \mathrm{Sr}, \mathrm{Ba}, \mathrm{Ni}$ in factor 2 does not show spatial dependence to the ore-forming process in the area. From mineralogical point of view, these groups of elements reflect the composition of some of the rock-forming minerals (feldspars, micas, amphiboles, etc.) in the host magmatic and/or metamorphic rocks in the studied district. The geological modeling of the
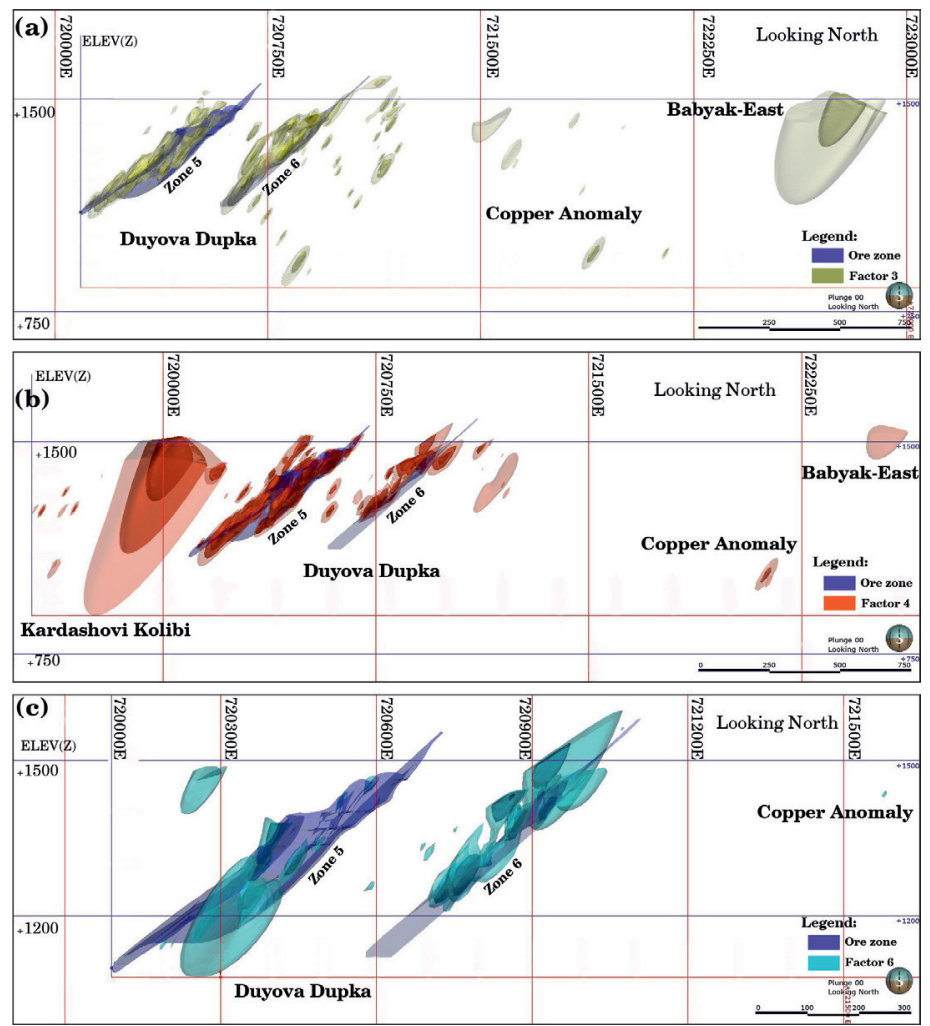

Fig. 1. Spatial distribution on part of the geochemical associations in the Babyak deposit: $a$, cross section of $([\mathrm{Zn}, \mathrm{Cd}] \mathrm{Pb}, \mathrm{Cu}) \pm \mathrm{Mn}$, $\mathrm{Au}, \mathrm{Fe}$ association (factor 3); $b,([\mathrm{Bi}, \mathrm{Ag}] \mathrm{Mo}) \pm \mathrm{Pb}, \mathrm{Sb}$ association (factor 4); $c$, cross section of ([As, $\mathrm{Au}] \mathrm{Sb},(-\mathrm{Mn}))$ association 
next five factors is clearly related to the ore deposition. Factor 3 includes ([Zn, Cd] $\mathrm{Pb}, \mathrm{Cu}) \pm \mathrm{Mn}, \mathrm{Au}, \mathrm{Fe}$ association (Fig. 1a). This association is developed in several parts of the deposit mainly in different levels of the most promising section (Duyova Dupka) where the main ore zones ( 5 and 6 , respectively) are located. These elements obviously mark the distribution of ore minerals from the polymetallic stage of the deposit, such as sphalerite, galena, chalcopyrite, etc. (Stavrev et al., 2018). The ([Bi, Ag] Mo) $\pm \mathrm{Pb}$, Sb geochemical association of factor 4 has both a similar spatial behavior with the factor 3 anomalies along the main ore zones and forms independent ore clusters in the other parts of the deposit (Fig. 1b). The presence of these elements is most likely related to their distribution as micro-inclusions and incorporations in the molybdenite structure (Stavrev et al., 2020b). The elements from the $[\mathrm{Cr}, \mathrm{Ni}] \pm \mathrm{Mg}$, Co association (factor 5) are localized predominantly close to apophyses of the bigger ore zones and partly in the latter. The spatial distribution of this geochemical association suggests a relation of earlier and higher temperature pyrites corresponding to greisen-like and phyllic alteration in the deposit (Stavrev et al., 2018). Factor 6 (Fig. 1c) is represented by ([As, $\mathrm{Au}] \mathrm{Sb},(-\mathrm{Mn}))$ association. It is distributed similar to factors 3 and 4 in the Duyova Dupka section and rarer in the ore zones apophyses. The concentration of these elements may reflect other specific features of the polymetallic stage in the deposit. However, microscopic studies and trace element composition of the ore mineralization in this stage do not show clear dependence of $\mathrm{Au}$ and As, which is also confirmed by the ambiguous correlation $(+0.30)$ between them. The relatively higher negative value of Mn represents its inversely proportional relation tendency with this association. The distribution of factor 7 ([Ca] $\pm \mathrm{Mn}, \mathrm{W})$ is still poorly studied. This association is probably result of the presence of W-bearing phases (scheelite, hubnerite) observed and described in some cases. The geological model of factor 7 assumes its more limited spatial distribution as well as development in depth.

\section{Conclusions}

The new spatial data clearly demonstrate the distribution of the main associations of elements in the area of Babyak Mo-Ag-Au-W-Bi-base metal ore deposit. The 3D modelling of the factors (excluding first and second) illustrates the spatial zonation of the ore components. The development of higher temperature associations of elements (factor 4, 7 and partly factor 5) mainly in the western and southern parts of the deposit suggests that the precipitation of ore-bearing fluids begins in the fault zones of the granitoid batholith and at the contacts with orthogneisses of the metamorphic basement. The location of the other factors assumes that tectonic factors control the subsequent deposition of the lower temperature ore minerals. Based on the spatial-temporal relationships in the deposit, we suggest that ore/alteration mineral zones are products of multistage post-magmatic hydrothermal activity.
Acknowledgements: We thank Seequent Ltd. for the provided academic license of the Leapfrog Geo software used for 3D geological modelling, as well as Euromax Services Ltd. for the provided access to the data. The study is partly supported by the KP-06-N34/4 project of the Bulgarian National Science Fund.

\section{References}

Georgiev, V., Ph. Machev, A. Vlahov, V. Mladenova, A Hikov, B. Vidinli. 2019. The Rhodope Metallogenic Province in Bulgaria. Prof. Marin Drinov Publ. House BAS, 214 p. (in Bulgarian with English summary).

Deltchev, A., S. Dimitrov. 1964. Géologie et particularités géochimiques du gisement Babiak - Blagoevgrad. - Ann. de la Direction Générale de Géologie, 15, 5-34 (in Bulgarian with French abstract).

Ivanov, Zh. 2017. Tectonics of Bulgaria. Sofia, St. Kliment Ohridski Univ. Press, 332 p. (in Bulgarian with English abstract).

Kamenov, B., I. Peytcheva, L. Klain, K. Arsova, Y. Kostitsin, E. Salnikova. 1999. Rila-West Rhodopes Batholith: Petrological and geochemical constraints for its composite character. - Geochem., Mineral., and Petrol., 36, 3-27.

Peytcheva, I., A. von Quadt, V. Kostov-Kytin, M. Kadiyski, M. Stavrev. 2021. U-Pb dating and composition of columbite from Vishteritsa: Implication for timing of granite magmatism and rare-element granitic pegmatites in the Western Rhodopes, Bulgaria. - Geologica Carp., 72, 3, 195-212; https://doi.org/10.31577/GeolCarp.72.3.2.

Popov, K. 2002. Geochemical association in Radka ore district. - Ann. Univ. Mining and Geol., 45, 1-Geol., 57-63.

Popov, K. 2016. 3D Modelling of the geochemical associations in the Assarel porphyry-copper deposit (Bulgaria). - C. R. Acad. bulg. Sci., 69, 9, 1175-1182.

Popov, K., P. Popov. 2019. The Alpine late collisional RilaRhodope Metallogenic Zone of the Balkan Orogenic System. - Rev. Bulg. Geol. Soc., 80, 1, 55-79.

Sarov, S. 2012. Lithotectonic subdivision of the metamorphic rocks in the area or Rila and Rhodope Mountains - results from geological mapping at scale 1:50 000. - In: Proc. Inter. Conf. the School of Prof. Zivko Ivanov. Sofia, 43-47.

Sarov, S., N. Georgiev, K. Naydenov, E. Voinova, K. Kolcheva. 2008. Lithotectonic subdivision of the Western Rhodopes and parts of Eastern Pirin. - Proc. Nat. Conf. Bulg. Geol. Soc., Geoscences 2008, 89-90.

Stavrev, M., A. Hikov, I. Peytcheva, E. Stefanova. 2018. Geochemical features of the hydrothermal alterations and basemetal ore mineralization near the village of Babyak, Western Rhodopes (Bulgaria): preliminary results. - Rev. Bulg. Geol. Soc., Geoscences 2018, 79, 3, 59-60.

Stavrev, M., I. Peytcheva, A. Hikov, R. D. Vassileva, A. von Quadt, M. Guillong, V. Grozdev, Y. Plotkina. 2020a. Late Cretaceous magmatism in part of the Western Rhodopes (Bulgaria): U-Pb dating on zircon and grossular-andradite garnets. - C. R. Acad. bulg. Sci., 73, 4, 522-530; http:// dx.doi.org/10.7546/CRABS.2020.04.11.

Stavrev, M., R. Craeser, I. Peytcheva, A. Hikov, S. Chavdarova. 2020b. First Re-Os age dating of molybdenite from Babyak Mo-Ag-Au-W-Bi-base metal deposit: evidence for Early Eocene fertile magmatic-hydrothermal system in Western Rhodopes, Bulgaria. - Rev. Bulg. Geol. Soc., Geoscences 2020, 81, 3, 93-95.

von Quadt, A., I. Peytcheva. 2005. The southern extension of the Srednogorie type Upper Cretaceous magmatism in RilaWestern Rhodopes: Constraints from isotope-geochronological geochemical data. - Proc. Nat. Conf. Bulg. Geol. Soc, Geosciences 2005, 113-116. 